\title{
Comparative study of Azathioprine and Cyclosporin in rheumatoid arthritis - a sixteen weeks follow-up study
}

\author{
R. Aggarwal ${ }^{*}$, H. Singh ${ }^{*}$, M.S. Gupta ${ }^{*}$, J.S. Hans ${ }^{* *}$, Kiranjit Kaur ${ }^{* *}$
}

\begin{abstract}
Abstrak
Artritis reumatoid ialah penyakit poliartritis kronik progresif yang menimbulkan deformasi, meliputi multisistem dan disertai morbiditas yang nyata. Obat-obatan imunosupresif telah digunakan untuk mengurangi/menghambat progresi penyakit. Penelitian ini diadakan untuk membandingkan keberhasilan azatioprin dan siklosporin pada penderita artritis reumatoid. Penelitian meliputi 100 penderita artritis reumatoid (sesuai kriteria American Rheumatism Association, 1987) yang dibagi atas dua kelompok: kelompok I mendapat azatioprin $1 \mathrm{mg} / \mathrm{kg} / \mathrm{h}$ dan kelompok II mendapat siklosporin 2,5-3,0 mg/kg/h selama 16 minggu. Penilaian keberhasilan berdasarkan parameter klinis, biokimiawi dan radiologis. Semua penderita menunjukkan perbaikan nyata (nilai $p<0.001)$ pada semua parameter klinis, yaitu hilangnya nyeri, berkurangnya kekakuan pagi hari, sendi yang nyeri/membengkak dan waktu yang diperlukan untuk berjalan sejauh 50 kaki serta menguatnya kekuatan genggaman. Semua penderita menunjukkan penurunan LED ( $p$ $<.001)$ tanpa perubahan apapun pada titer faktor reumatoid. Kedua obat menunjukkan keberhasilan yang sama (nilai $p$ tidak bermakna) dalam hal perbaikan parameter klinis dan biokimiawi. Tetapi dengan siklosporin erosi tulang dan osteoporosis yukstaartikular lebih banyak berkurang. Sepuluh penderita menunjukkan nefrotoksisitas dengan siklosporin. Siklosporin lebih baik dari azatioprin dalam hal mengurangi derajat progresi kelainan sendi pada artritis reumatoid, tetapi insidens efek samping lebih tinggi, yang pada umumnya dapat diatasi. (Med J Indones 2002; 11: 153-7)
\end{abstract}

\begin{abstract}
Rheumatoid Arthritis (RA) is a chronic progressive deforming polyarthritic disease involving multisystems and associated with considerable morbidity. Immunosuppressive drugs have been used to reduce/arrest the progression of the disease. The present study was undertaken to compare the efficacy of Azathioprine and cyclosporin in Rheumatoid Arthritis patients. Study consisted of 100 patients of Rheumatoid Arthritis (as per criteria of American Rheumatism Association, 1987) divided into two groups : group I received Azathioprine $1 \mathrm{mg} / \mathrm{kg} / \mathrm{d}$ and group II received cyclosporin 2.5-3.0 mg/kg/d for 16 weeks. Assessment of efficacy was based on clinical, biochemical and radiological parameters. All patients showed marked improvemen ( $p$ value < 0.001$)$ in all clinical parameters i.e. relief in pain, reduction in morning stiffness, painful/swollen joint along with walking time for 50 feet and increase in grip strength. All patients showed reduction $(p<0.001)$ in ESR without any change in rheumatoid factor titres. Both drugs showed equal efficacy $(p$ value $=N S$ ) in improvement of clinical and biochemical parameters. But cyclosporin showed more reduction in bony erosions and juxtaarticular osteoporosis. Ten patients showed nephrotoxicity with cyclosporin. Cyclosporin has an edge over azathioprine in reducing the rate of progression of joint change in Rheumatoid Arthritis but is associated with increased incidence of side effects that are generally manageable. (Med J Indones 2002; 11: 153-7)
\end{abstract}

Keywords: azathioprine, cyclosporin, rheumatoid arthritis

Rheumatoid arthritis is the commonest form of chronic inflammatory joint disease which usually on chronicity becomes multisystem disease. The course of rheumatoid arthritis is typically prolonged, despite exacerbations and remissions, is associated with significant morbidity and mortality. ${ }^{1}$

\footnotetext{
* Department of Medicine, Pt. B.D. Sharma PGIMS, Rohtak124001 Haryana, India

** Department of Biochemistry, Govt. Medical College, Patiala, India
}

The etiology of rheumatoid arthritis remains obscure although various theories have been put forward. It is generally agreed that it is an autoimmune disease that involves both humoral and cellular arms of immune response. $^{2,3}$ A complex interaction of genetic, immunological and local factors are involved to account for the different patterns of joint involvement and progression of disease among patients with rheumatoid arthritis. Viral (eg. Lentivirus) and other nonspecific infections may also be involved in the initiation and for exacerbation of the disease.,3 
Nevertheless, the reason for the persistence and fluctuation of rheumatoid inflammation are poorly understood as ideas include persistent antigenic stimulation with alternating cycles of positive and negative responses. ${ }^{3}$ There are repeated introduction of antigens into the synovium, each followed by the evaluation and resolution of immune reaction. ${ }^{3}$

Since the etiology of the disease is largerly unknown, so therapy is directed mainly to decrease synovial inflammation, to provide relief from pain, to prevent complications and to arrest disease progression in patients suffering from rheumatoid arthritis.

Various drugs for treating rheumatoid arthritis are used nonsteroid antiinflammatory, slow acting antirheumatic drugs (chloroquine, penicillamine, sulphasalazine, gold salts), corticosteroids and immunosuppressive drugs eg. azathioprine, cyclophosphamide, methotrexate and cyclosporin $^{4}$

Both azathioprine and cyclosporin have been widely used in treating the patients of rheumatoid arthritis individually but not many studies have been carried out comparing these two drugs. So this study was taken up to compare the efficacy as well as tolerability of azathioprine and cyclosporin in patients of rheumatoid arthritis.

\section{METHODS}

Hundred patients of rheumatoid arthritis visiting as outpatient department of our institution were included in the study.

A written consent was taken after making aware each patient about the drug trial and possible side effects of the drug. Diagnosis of rheumatoid arthritis was made as per American Rheumatism Association 1987 revised criteria. ${ }^{5}$ Those (a) previously treated with azathioprine and cycloporin, (b) with total leucocyte count less than $4000 / \mathrm{m}^{3}$ (polymorph count below $50 \%$ ) (c) with platelet count below $200,000 / \mathrm{m}^{3}$ (d) with abnormal liver function tests. (c) with blood urea above $50 \mathrm{mg} \%$ and (f) pregnant females, were however excluded.

Two groups of fifty patients each on random basis were formed. The first group were put on azathioprine $1 \mathrm{mg} / \mathrm{kg}$ daily and the second group were put on cyclosporin $2.5-3.0 \mathrm{mg} / \mathrm{kg}$ daily for a period of 16 weeks. Investigations were done at the start of the trial, at 8 weeks and at the end of the study i.e. 16 weeks. Patients were called for follow up initially weekly for two weeks and then fortnightly till the end of the study to see the clinical improvement and also the side effects of the drugs (if any).

Clinical criteria for drug efficacy

1. Morning stiffness : patients were asked about the duration of morning stiffness which was noted in minutes.

2. Grip strength : rubber band of sphygmomanometer was inflated to $30 \mathrm{~mm}$ of mercury before testing. Patient was then asked to squeeze the bag as hard as possible and then to maintain pressure, the mercury level was recorded at the height maintained by the patient while squeezing the bag. Patient squeezed the bag with each hand and the mean reading (in $\mathrm{mmHg}$ ) were recorded for both hands.

3. Walking time for fifty feet : patient was asked to walk fifty feet at a normal pace and time taken by the patients was recorded in seconds by a stop watch.

4. Pain intensity : three classes of pain were considered : (a) Severe - pain which was not tolerable and so patient was unable to move the joint. (b) Moderate : pain was present but patient was able to tolerate it with movement (c) Slight : patients complained of mild pain but could move about without any difficulty.

5. Swollen joints : the number of swollen joints at time was counted.

6. Functional ability : patient's functional ability was graded according to the American Rheumatism Association criteria as (a) complete function without handicap (b) adequate function with discomfort (c) limited function with little or no ability to perform duties (d) completely incapacitated.

The above six clinical criteria (1 to 6) were compared to their basal value (at entry time).

Besides clinical, haematological and radiological investigations were also performed in each patient during 16 weeks of follow up, i.e. at start, 8 weeks and 16 weeks of therapy, these were :

1. Serological improvement (rheumatoid factor): rheumatoid factor level in the serum of the patients were detected by "Rapid Latex Agglutination Slide Test" with the kit supplied by Ranbaxy Laboratories. The results obtained 
indicated the amount of rheumatoid factor $(10 / \mathrm{ml})$ present in the sample.

2. ESR : ESR was measured using Wintrobe tube at 8 weeks interval and changes from basal value compared.

3. radiological changes : plain skiagram of hands including wrist were performed and compared for osteoporosis, bony erosions and periosteal reaction at 2 monthly basis.

\section{RESULTS}

All hundred patients, divided into two groups, completed the study protocol.

(I) Demographic data : the mean age of group I was $44.54 \pm 16.04$ years and that of group II was $42.50 \pm 18.16$ years $(p$ value NS). Females outnumbered males and male female ratio of the two groups was $1: 7.1$ group I and $1: 4$ for group II.

(II) Clinical results : all patients showed clinical improvement with either of the drug (Table 1) in all parameters which got better with increasing duration of follow-up.

(III) Investigational parameter :

(a) Rheumatoid factor : both positivity rate and dilutional factor reduced with therapy (Table 2).

(b) ESR : ESR showed gradual downward trend with both drugs (Table 2).

(c) Radiological finding : there was reduction in soft tissue swelling in both groups. In the cyclosporin group, additionally, there was decrease in the number of erosions in two cases and improvement in juxtaarticular osteoporosis in three cases.

(IV) comparative data with two groups : both drugs were equally clinically effective as well on investigational parameter ( $p$ value NS) except that cyclosporin showed better radiological regression trends (Table 3 ).

\section{Adverse effects}

Sixteen patients of group I and 18 patients of group II experienced minor side effects during their 16 weeks follow-up (Table 4).

Table 1. Showing mean values of clinical parameters

\begin{tabular}{llccccc}
\hline \multirow{2}{*}{ Parameter } & \multicolumn{3}{c}{ Group 1 } & \multicolumn{3}{c}{ Group 2 } \\
\cline { 2 - 7 } & 0 wk. & 8 wk. & 12 wk. & 0 wk. & 8 wk. & 12 wk. \\
\hline Morning stiffness (in minutes) & 78.06 & 57.62 & 41.20 & 86.72 & 70.22 & 53.04 \\
Grip strength (in mmHg) & 66.28 & 70.88 & 78.64 & 70.52 & 75.26 & 81.52 \\
Walking time (in seconds) & 21.60 & 20.30 & 19.40 & 21.78 & 20.70 & 19.76 \\
Number of swollen joints & 7.30 & 6.34 & 5.10 & 7.30 & 6.22 & 5.16 \\
No pain (no. of patients) & 0 & 2 & 24 & 0 & 6 & 21 \\
Complete functional (no. of patients) & 6 & 10 & 17 & 2 & 6 & 18 \\
\hline
\end{tabular}

Table 2. Showing investigational parameters

\begin{tabular}{llccccc}
\hline \multirow{2}{*}{ Parameter } & \multicolumn{3}{c}{ Group 1 } & \multicolumn{3}{c}{ Group 2 } \\
\cline { 2 - 7 } & 0 wk. & 8 wk. & 12 wk. & 0 wk. & 8 wk. & 12 wk. \\
\hline Mean ESR (in mmHg) & 46.16 & 37.70 & 33.74 & 38.02 & 32.32 & 27.80 \\
$\begin{array}{l}\text { Positivity of rheumatoid factor } \\
\text { (no. of cases) }\end{array}$ & 45 & 38 & 32 & 44 & 36 & 28 \\
\hline
\end{tabular}


Table 3. Comparative data at 12 weeks

\begin{tabular}{lccccc}
\hline & \multicolumn{4}{c}{ Response to drug } & \multicolumn{2}{c}{$\begin{array}{c}\text { Relation of } \\
\text { p value of } \\
\text { garameter }\end{array}$} & \multicolumn{2}{c}{$\begin{array}{c}\text { Azathioprine } \\
\text { (Group 1) }\end{array}$} & \multicolumn{2}{c}{$\begin{array}{c}\text { Cyclosporine } \\
\text { (Group 2) }\end{array}$} & $\begin{array}{c}\text { and } \\
\text { group 2 }\end{array}$ \\
\cline { 2 - 5 } & $\begin{array}{c}\text { At 16 } \\
\text { wks }\end{array}$ & $\begin{array}{c}\text { P value } \\
\text { (baseline) }\end{array}$ & $\begin{array}{c}\text { At 16 } \\
\text { wks }\end{array}$ & $\begin{array}{c}\text { P value } \\
\text { (baseline) }\end{array}$ & NS \\
\hline $\begin{array}{l}\text { Reduction in morning } \\
\text { stiffness (in minutes) }\end{array}$ & 36.86 & $<0.001$ & 33.68 & $<0.001$ & NS \\
$\begin{array}{l}\text { Gain in grip strength } \\
\text { (in mmHg) }\end{array}$ & 12.36 & $<0.001$ & 11.0 & $<0.001$ & NS \\
$\begin{array}{l}\text { Reduction in walking time } \\
\text { (in seconds) }\end{array}$ & 2.20 & $<0.001$ & 2.02 & $<0.001$ & NS \\
$\begin{array}{l}\text { Reduction in number of } \\
\text { swollen joints }\end{array}$ & 2.20 & $<0.001$ & 2.14 & $<0.001$ & \\
\hline
\end{tabular}

Table 4. Showing adverse effects

\begin{tabular}{lcc}
\hline Adverse effects & $\begin{array}{c}\text { Group 1 } \\
\text { Azathioprine }\end{array}$ & $\begin{array}{c}\text { Group 2 } \\
\text { Cyclosporin }\end{array}$ \\
\hline Nausea \& vomiting & 10 & 6 \\
Diarrhea & 6 & Nil \\
Impaired LFT & - & 1 \\
Impaired renal function & - & 10 \\
Hypertension & - & 1 \\
\hline
\end{tabular}

\section{DISCUSSION}

Current concepts suggest that rheumatoid arthritis is an immunological disorder that involves both cellular and humoral arms of immune response. Immunosuppressive agents like, azathioprine and cyclophosphamide, have been used as reserve drugs for difficult patients who failed on various DMARD's agent since 1950's. With recent insights into the immunopathogenesis of rheumatoid arthritis and the central role for the T-cell in the disease pathogenesis, the rationale of using cyclosporine in rheumatoid arthritis has found firm basis. ${ }^{8,9}$

Both groups i.e. azathioprine and cyclosporin, showed significant improvement ( $\mathrm{p}$ value $<.001$ ) (Table 1 and 3 ) in all clinical parameters, i.e. reduction in morning stiffness, gain in grip strength, reduction in walking 50 feet time, reduction in number of swolen joints and pain intensity and lastly improvement in functional capacity. These observations are supported by other authors. ${ }^{10-18}$
Both drugs compared to each other were equally effective ( $p$ value NS), an observation in clinical parameter also shared by two other similar comparative studies. ${ }^{12,16}$ But Forre et al observed that cyclosporin improved significantly 50 feet walk time, circumferences of proximal interphalangeal joints (an observation not measured in the present study), Ritchie Articular index and grip strength whereas azathioprine only improved grip strength. ${ }^{10}$

ESR, a good parameter for inflammatory activity, was significantly reduced ( $p$ value $<.001)$ by both drugs, an observation supported by other authors. ${ }^{10-18}$ The comparative reduction of ESR in both groups was comparable ( $p$ value NS), a finding observed by other workers. ${ }^{10,12,16}$ The concentration of rheumatoid factor in blood and synovial fluid is a measure of severity of the disease. ${ }^{19}$ The seroconversion of rheumatoid factor was slightly significant in both groups ( $p$ value 0.05 ) but not comparable ( $\mathrm{p}$ value NS) between each other. Cyclosporin has been noticed to reduce 
radiological progression by other workers as was in our present study, as compared to the azathioprine group. ${ }^{20}$

Immunosuppressive therapy cause a variety of toxic side effects, but in the present study in spite of sideeffects noticed none of the patients withdrew. In the cyclosporin treated group, $20 \%$ patients showing slight worsening of renal function, which may be due to fixed drug dosage in the present rather that suggested "go low, go slow" method for cyclosporin." Initially the nephrotoxicity is functional rather than morphologic whose presume cause is an alternation in internal haemodynamic function and if through plasma levels of more than $250 \mathrm{~g} / \mathrm{L}$ maintained constantly, then may lead to irreversible renal impairment. ${ }^{21}$

From the above discussion it may be concluded that both azathioprine and cyclosporin showed improvement in various disease activity parameters and so finally functional capacity. Further cyclosporin has got an edge over azathioprine in reducing the rate of progression of joint damage. The incidence and severity of side effects are more with cyclosporin but these are known and manageable.

So unlike the fear associated with use of immunosuppressive drugs, both azathioprine and cyclosporin are effective and relatively safe drugs for use in rheumatoid arthritis provided dosage is railored to patient's requirement.

\section{REFERENCES}

1. Pincus T, Callahan LF. The side effects of rheumatoid arthritis : Joint destruction, disability and early mortality. Br J Rheumatol 1993; 32 (1):28-37.

2. Zeidler HK, Kvein TK, Hannoren P, Forre O, Laasonen L, Markert ER et al. Progression of joint damage in early active rheumatoid arthritis during 18 months of treatment : comparison of low dose cyclosporin and parental gold. $\mathrm{Br}$ J Rheumatol 1998; 37 (8):874-82.

3. Dinarello CA. Biology of interleukin. FASEB J 1988; 2:108-15.

4. Hensen TM, Kryger P, Elling H. Double blind control trial of pulse treatment with methyl prednisolone combined with disease modifying drugs in rheumatoid arthritis. Br Med J 1990; 301; 268-70.

5. Arnett FC, Edworthy SM, Bloch D. The American Rheumatism Association 1987. Revised criteria for classification of rheumatoid arthritis. Arthritis Rheum 1988; 31:315-24.
6. Gaffney K, Scott DG. Azathioprine and cyclophosphamide in the treatment of rheumatoid arthritis. Br J Rheumatol 1998; 37:824-36.

7. Suarez-Almazor ME, Spooner C, Belseck E. Azathiopurine for rheumatoid arthritis. Cochrane Database Syst Rev 2000; 2:CD001461.

8. Dougados M, Awada H, Amor B. Cyclosporin in rheumatoid arthritis : a double blind, placebo controlled study in 52 patients. Ann Rheum Dis 1988; 47:127-33.

9. Tugwell P, Bombardeer C, Gent M. Low dose cyclosporin versus placebo in patients with rheumatoid arthritis. Lancet 1990; 335:1051-5.

10. Forre O, Bjerkhoel F, Salvesen CF, Berg KJ, Rugstad HE, Saelid $\mathrm{G}$ et al. An open, controlled, randomised comparison of cyclosporin and azathioprine in the treatment of rheumatoid arthritis : A preliminary report. Arthritis Rheum 1987; 30 (1):88-92.

11. Forre O. The Norwegian Arthritis Study Group. Cyclosporin A in rheumatoid arthritis : A double blind, placebo controlled study. Scandinavian J Rheumatology 1990; 19 (85):57.

12. Ahern MJ, Harrison W, Hallingsworth P, Bradley J, Laing B, Bayles C. A randomised double blind trial of cyclosporin and azathioprine in refractory rheumatoid arthritis. Aust NZ J Med 1991; 21 (6):844-9.

13. Madhok R, Torley HI and Capell HA. A study of the long term efficacy and toxicity of cyclosporin in rheumatoid arthritis. J Rheumatol 1991; 18 (10):1485-9.

14. Cseuz R, Zimmerman J and Panayi GS. Dialy and alternate day azathioprine in rheumatoid arthritis : A 12 week control clinical trial. Br J Rheumatol 1992; 31 (7):501-2.

15. Wells G, Tugwell P. Cyclosporine A in rheumatoid arthritis : overview of efficacy. Br J Rheumatol 1993; 32 (1):51-6.

16. Kruger K, Schattenkirchner M. Comparison of cyclosporin-A versus azathioprine in the treatment of rheumatoid arthritis. Clin rheumatol 1994; 13 (2):245-55.

17. Kautiainen H, Savolainen HA, Isomaki H, Aho K and Verronen P. Azathioprine in patients with juvenile chronic arthritis. A long follow-up study. J Rheumatol 1997 : 24 (12):2444-50.

18. Yocum D, Klippel JH, Wilder RL. Cyclosporin-A in severe, refractory rheumatoid arthritis : A randomized study. Ann Intern Med 1998; 109:863-9.

19. Harris ED. Rheumatoid arthritis pathology and implication for therapy (A succinet review of the current understanding to the nature of genetic and immunological factors in the pathogenesis of rheumatoid arthritis). N Engl J Med 1990; 322:1277-82.

20. Forre O. Radiological evidence of disease modification in rheumatoid arthritis patients treated with cyclosporin. Arthritis Rheum 1994; 37 (Suppl. 10) : 1506-12.

21. English J, Evans A, Houghton DC and Benwett WM. Cyclosporin induced acute renal dysfunction in the rat: evidence of arteriolar vasoconstriction and prevention of tubular function. Transplantation 1987; 44:135-41. 